MELUZYNA

ISSN 2449-7339

\section{2 (11) (2019) | Rocznik VI}

DOI: 10.18318/me.2019.2-02

PRZEKROJE | ZBLIŻENIA

\author{
Żaneta Polanin* \\ Uniwersytet Łódzki \\ ORCID ID 0000-0002-1419-3742
}

\title{
Dydaktyka w Wirydarzu krześcijańskim Jakuba Lubelczyka
}

Klasztorne wirydarze stanowiły miejsce kontemplacji i wzrastania duchowego. Potrzeba tworzenia ogrodów związana była $\mathrm{z}$ tęsknotą człowieka za utraconym rajem. Przestrzenie te pomagały skupić się na rozważaniach, modlitwie, a w konsekwencji umożliwiały zbliżenie się do Boga. Klasztorne wirydarze charakteryzowały się konstrukcją zamkniętą. Od świata zewnętrznego odgradzały je mur lub roślinność, co wzmacniało poczucie bezpieczeństwa oraz przekonanie o czystości tej przestrzeni, odciętej od grzechu (Ciołek, 1978, s. 18-19; Kuran, 2014, kol. 685-687; Krenz, 2005, s. 91-108).

W literaturze wirydarze utożsamiane są z utworami o uporządkowanej, zamkniętej konstrukcji (Kuran, 2014, kol. 685). Tradycja przyrównywania dzieła literackiego do ogrodu sięga starożytności, spotykamy się z nią u Platona, który w dialogu Fajdros porównał utwór literacki do ogrodu, a pracę pisarza do czynności wykonywanych przez ogrodnika (Meller, 2009, s. 11). W tekstach Cycerona oraz Kwintyliana również pojawia się ta analogia (Dąbkowska, 1997, s. 11-14). W literaturze chrześcijańskiej zwyczaj pisania wirydarzy zapoczątkowali Ojcowie Kościoła, którzy teksty z sentencjami moralnymi nazywali „zbiorami kwiatów” przez wzgląd na ich pożyteczność i religijną wartość (Skwarczyńska, 1969, s. 54); tradycję tę podjął później m.in. św. Franciszek z Asyżu (Kuran, 2014, kol. 685). Użycie słowa „kwiatki” wskazywało na wybór tego, co najlepsze, najbardziej wartościowe $\mathrm{z}$ tematyki religijnej. W dawnej polszczyźnie częściej niż określenia „wirydarz” do tytułowania zbiorów modlitw używano nazw „ogród” lub „raj” (Kuran, 2014, s. 685). W literaturze polskiej utwory, których nazwy nawiązują do motywu ogrodu, to np.: Raj duszny (1513-1514) Biernata z Lublina, Wirydarz abo kwiatki rymów duchownych (1607) Stanisława Grochowskiego, Wirydarz poetycki (1675) Jakuba Teodora Trembeckiego, Ogród Panieński (1691) Wespazjana Kochowskiego oraz Ogród [...] nie plewiony (1690-1691) Wacława Potockiego (Eustachiewicz, 1975, s. 3).

\footnotetext{
* e-mail autorki: zpolanin@interia.pl
} 
Celem niniejszego studium jest omówienie sposobów funkcjonowania dydaktyzmu w Wirydarzu krześcijańskim Jakuba Lubelczyka. Osią rozważań będzie charakterystyka bohatera. Poprzez rozmowę z przewodnikami i chęć samodoskonalenia wyznacza on etapy przemiany duchowej człowieka. W obszarze zainteresowania znajdzie się rozpoznanie wskazówek moralnych oraz idei podanych w utworze (takich jak: cierpienie oraz jego celowość; wędrówka człowieka jako doskonalenie się na drodze wiary; życie w znaczeniu nieustannej walki z tym, co oddala od Boga), formułowanych $z$ perspektywy myśli reformacyjnej, a także sposób ich przekazania. Istotne będzie wskazanie funkcji środków, jakimi posługuje się autor, by wpłynąć na odbiorcę.

Badania nad Wirydarzem krześcijańskim zapoczątkowano w XIX wieku. Druk ten został odnaleziony przez Bolesława Erzepkiego we wrocławskiej Bibliotece Miejskiej. Uczony poświęcił temu dziełu artykuł, w którym opisał strukturę i zasygnalizował artystyczne walory utworu, takie jak „ujmująca prostota wykładu oraz niepoślednia piękność języka” (Erzepki, 1883, s. 1-2).

O życiu autora Wirydarza - Jakuba Lubelczyka, niewiele wiadomo. Najprawdopodobniej urodził się w 1530 roku w Lublinie, zmarł natomiast po roku 1567. Nieznane jest też miejsce jego nauki, wiadomo jednak, że biegle posługiwał się łaciną i polszczyzną oraz, być może, językiem niemieckim, czego dowodzą przekłady dokonywane przez tego pisarza. Swój talent literacki oraz znajomość teologii wykorzystywał jako zwolennik reformacji, tworząc pieśni, modlitwy oraz tłumacząc psalmy. Związek Lubelczyka ze stronnictwem innowierczym poświadcza obecność pisarza na licznych synodach, np. włodzisławskim, który odbył się 27 czerwca 1555 roku. Zapiski z tego synodu informują również, że autor Wirydarza był prawdopodobnie sekretarzem oraz współpracownikiem Mikołaja Reja. W 1558 roku wydał Lubelczyk w drukarni Wirzbięty kalwiński przekład Psałterza, w tym samym roku ukazał się Wirydarz, a w 1563 roku zaginiony utwór pt. Joba, onego sprawiedliwego męża, cierpliwość $i$ wiara. Pisarz tworzył także wiersze dedykacyjne oraz pochwalne (Meller, 2009, s. 5-6).

Ważną datą w rozwoju dorobku literackiego Jakuba Lubelczyka był rok 1558 - wtedy wydał Wirydarz krześcijański pięknie przyprawiony... (Meller, 1980, s. 135-140). Jest to dialog alegoryczny (zob. Sayers, 1975, s. 195-216; Tuve, 1975, s. 177-190) spełniający funkcje moralizatorskie. Lubelczyk wykreował świat, po którym przechadza się Krześcijanin (uczeń) wraz ze swymi nauczycielami: Aniołem oraz Duchem Świętym. Celem ich rozmów jest zapoznanie czytelników z ideami reformacyjnymi. Autor, świadomy trudów ziemskiej wędrówki, daje ludziom swoje dzieło jako przewodnik, by uchronić ich od zejścia z drogi wyznaczonej przez Pismo Święte. Utwór Lubelczyka ze względu na wyjątkową estetycznie formę oraz sposób wpływania na odbiorcę stanowi interesujący materiał, jednak do tej pory zajmowali się nim nieliczni uczeni (Pollak, 1964, s. 457-459).

Pracę Bolesława Erzepkiego (Erzepki, 1883, s. 1-2) kontynuowała po niemalże stu latach zapomnienia Katarzyna Meller. W artykule z 1980 roku omawia elementy świata przedstawionego utworu - bohaterów oraz przestrzeń symboliczną (Meller, 1980, s. 135-140). Zwraca także uwagę na dialogową konstrukcję, co wiąże z parenetycznym charakterem dzieła. Lubelczyk zrezygnował z wprowadzenia ideowego konfliktu, co sprawia, że Wirydarz przypomina ,jednogłosowy traktat” (Meller, 1980, s. 138). Badaczka jako pierwsza odniosła się do znaczenia tytułu oraz jego kulturowej tradycji. Meller nie wymienia konkretnych dzieł będących inspiracją dla Wirydarza, snuje jednak przypuszczenia, że Lubelczyk mógł czerpać z utworów o pokrewnej tematyce. 
Wyniki studiów nad źródłami tekstu Lubelczyka uczona przedstawiła w kolejnych publikacjach. Jako utwór, który może nasuwać skojarzenia z Wirydarzem, przywołuje Oeconomię albo Gospodarstwo Pseudo-Seklucjana z 1545 roku (Meller, 1990, s. 11). Nawiązań upatrywać można również w Wizerunku Mikołaja Reja, z którym Jakub z Lublina współpracował. Wiadomo, że dzieła Nagłowiczanina stanowiły dla Lubelczyka wzór i inspirację. Badaczka jednocześnie zaznacza, że w Wirydarzu autor zostawił sygnały sugerujące, iż jego dzieło może być przekładem lub przeróbką innego tekstu.

Meller omawia szerzej kwestię poszukiwań pierwowzoru i charakteryzuje związki we wstępie do krytycznego wydania utworu Lubelczyka (Meller, 2009, s. 8). Dostrzega relację Wirydarza z dziełem Michaela Bocka, niemieckiego przedstawiciela luteranizmu, zatytułowanym Würtzgertlein für die kranken Seelen, najprawdopodobniej wydanym w 1560 roku (Meller, 2009, s. 7). Tytuł oraz alegoryczna struktura są elementami, które mogły stanowić inspirację dla tekstu Lubelczyka. Autor w dedykacji do Wirydarza dziękuje swojemu przyjacielowi Jakubowi Zutterowi za bliżej nieokreślony prezent. Meller przypuszcza, że Lubelczyk otrzymał właśnie wydanie utworu Bocka. Badaczka wspomina również o tym, że najsłynniejszy poeta węgierskiego odrodzenia Bálint Balassi przetłumaczył i wydał w krakowskiej drukarni Wirzbięty utwór Würtzgertlein für die kranken Seelen... Balassi znał także Psałterz Dawida w wersji przełożonej przez Lubelczyka, ponieważ na jego podstawie przetłumaczył na język węgierski jeden z psalmów (Meller, 2009, s. 7-8). Ten fakt, według Meller, może być kolejną wskazówką pozwalającą przypuszczać, że Wirydarz inspirowany był dziełem Bocka.

Istotną cechą charakterystyczną omawianego tekstu Lubelczyka jest dydaktyzm, obecny na kilku płaszczyznach utworu. Meller podkreśla edukacyjny cel Wirydarza poprzez nazwanie go parenetyczym dialogiem alegorycznym. W XVI wieku powszechne było przekonanie o zdolności człowieka do moralnego samodoskonalenia i roli pisarza, jaką jest wychowywanie czytelników. Myśliciele protestanccy kładli szczególny nacisk na wywyższanie dobrego postępowania ponad wiedzę teologiczną, która samodzielnie nie jest w stanie zapewnić zbawienia. Badaczka zaznacza, że Wirydarz jest przykładem realizacji „parenetyki chrześcijańskiej o profilu ewangelickim” (Meller, 2009, s. 8) i stanowi wskazówkę dla ówczesnych odbiorców, jak zachować czyste sumienie. Alegoryczny charakter dzieła, według badaczki, zaobserwować można we wszystkich elementach świata przedstawionego, np. w konstrukcji ogrodu, roślinach i lekarstwach.

Do rozważań nad Wirydarzem termin „mistyczna botanika” wprowadziła Joanna Maleszyńska. Lubelczyk, sięgnąwszy po terminologię związaną z roślinnością, tłumaczy czytelnikowi prawdy religijne. Jako przykład badaczka podaje zioło, które nie tylko przypomina ofiarę Zbawiciela, ale pełni również funkcję nakazu moralnego (Maleszyńska, 1984, s. 28-29). Dla Lubelczyka, jak wyjaśnia Maleszyńska, Pismo Święte jest ogrodem, Bóg ogrodnikiem, a „wonne kwiateczki” to „parenetyczne przestrogi, ideały i wzory do naśladowania” (Maleszyńska, 1984, s. 28).

Godne uwagi jest ustalenie, jak Lubelczyk rozumiał formę wirydarza. W jego dziele czytamy:

A iż jest na kształt ogródka jakiego abo wirydarza sprawiona, to dlatego, aby czytelnikowi krześcijańskiemu Pismo Święte zapachem smakowało, aby się w swym utrapieniu a prześladowaniu cieszył tymi wonnymi kwiateczkami, to jest obietnicami, których jest pełno w tym świętym wirydarzu Pisma Świętego, 
ku pociesze wszystkich wiernych a krześcijańskich ludzi przez Ducha Świętego naszczepionych a zostawionych (Lubelczyk, 2009, s. 23) ${ }^{1}$.

Utwór ma być podporą w chwilach zwątpienia, umacniać w wierze i być przewodnikiem po tych słowach Pisma Świętego, które mogą okazać się trudne do zrozumienia. Wirydarz, choć porusza tematykę krzyża i cierpienia, będących nieodzownym elementem ludzkiego życia, powinien dać nadzieję, że wszelkie niedogodności związane z podążaniem drogą wyznaczoną przez Boga zostaną wynagrodzone.

Lubelczyk ujął swoje dzieło w formę dialogu, który ma szczególne znaczenie w literaturze przez wzgląd na dydaktyczny, a nawet perswazyjny charakter (Abramowska, 2002a, s. 159). Rozmowa w Wirydarzu prowadzona jest między Krześcijaninem - uczniem, oraz Aniołem i Gospodarzem, czyli nauczycielem i mentorem. Postawa autora jako dydaktyka, wychowawcy miała decydujący wpływ na dzieło (Pelc, 1971, s. 129). Słowa przewodników nie są tu podawane w wątpliwość, Krześcijanin, będący odbiciem świadomości odbiorcy, nie ma kompetencji, aby z nimi dyskutować.

W utworze Lubelczyka wiodącą postacią jest Krześcijanin, ponieważ to on znajduje się w centrum rozważań moralnych, przechodzi duchową przemianę, z nim utożsamiać ma się odbiorca. Ponieważ bohater ten ma stanowić odbicie ludzkich postaw, być reprezentantem danej grupy lub nawet całej ludzkości, brak tutaj indywidualizacji postaci (Dąbrówka, 2001, s. 455). Krześcijanin, według Meller (Meller, 2009, s. 9), jest everymanem wywodzącym się z tradycji średniowiecznego moralitetu (Abramowska, 2002b, s. 626). Bohater pozornie stosuje się do słów Pisma Świętego, a w rzeczywistości podąża za ziemskimi dobrami. Dostaje jednak szansę na przemianę i stara się z niej skorzystać. Choć nie wszystko od razu rozumie, pokornie przyjmuje nauki przekazywane mu przez przewodników.

Do Krześcijanina jako pierwszy przychodzi Anioł. Lubelczyk w Argumencie podkreśla jego służebną rolę wobec człowieka. Jest posłem przysłanym przez Boga, by strzec zagubionych ludzi. Aniołowie należą do bytów konotujących bezpieczeństwo i łagodność. W literaturze staropolskiej, według Danuty Künstler-Langer, została im powierzona rola „opiekuna, interpretatora świata, przewodnika do domu Boga, komentatora losu jednostki, obrońcy przed mocami śmierci [...]" (Künstler-Langer, 2007, s. 215). W Wirydarzu krześcijańskim można znaleźć realizację tego założenia. Funkcja Anioła w dziele Lubelczyka jest znacząca, ponieważ to on na kartach utworu wygłasza większość upomnień. Na początku człowiek nie ma pewności, czy stawiane mu przez rozmówcę zarzuty są słuszne. Wstępna rozbieżność stanowisk stwarza możliwość pokazania procesu przemiany bohatera, stanowi też podsumowanie jego uprzedniej, nikłej świadomości w sprawach wiary. Anioł opowiada swojemu interlokutorowi o tym, że pochodzi z innego świata i dziwi go nieprawe zachowanie ludzi. Dzięki temu wyznaniu bohater rozpoznaje w towarzyszu boskiego wysłannika i zmienia nastawienie. Przyznaje, że dostrzega grzeszność swojego postępowania, ale nie wie, w jaki sposób je zmienić. Rozmowa tych dwóch postaci dotyka tematu dźwigania własnego krzyża oraz poczucia samotności w obliczu walki z grzechem.

1 Wszystkie cytaty z utworu pochodzą z tego wydania; dalej opatruję je skrótem W. i numerem strony. 
Kolejny rozmówca Krześcijanina to Duch Święty, przez Lubelczyka nazwany Gospodarzem. Utwierdza swojego ucznia w wierze i zapoznaje go z zawartością „apoteki”, czyli Psałterza, który ma uleczyć sumienie człowieka dzięki znajdującym się w nim lekarstwom. W wypowiedziach przewodników często pojawiają się cytaty z Biblii, co ma niewątpliwy związek z reformacyjną ideą samodzielnego czytania Pisma Świętego. Według Gospodarza jest to znacznie cenniejsze niż poznawanie słów Boga za pośrednictwem kaznodziejów. W Biblii można znaleźć odpowiedzi na wszystkie wątpliwości człowieka, dlatego obcowanie z nią powinno być nieodłączną częścią egzystencji wszystkich wierzących. Jednak samodzielna lektura może okazać się zbyt trudna, pojmowanie prawd wiary za pomocą rozumu może być zgubne, co ilustrują słowa: „[...] czym się ma cieszyć wierny, gdy przydzie na osobne tajemnice Pisma, którym ludzki rozum sprostać nie może” (W., s. 67). Odpowiedzią na wątpliwości Krześcijanina jest rozmowa z Duchem Świętym, który obdarowuje go umiejętnością rozumienia Pisma Świętego. Gospodarz cieszy się z obecności ucznia w swoim domu nie dlatego, że żyje bez grzechu i wie już wszystko o sprawach wiary, ale z powodu jego chęci nawrócenia się mimo dotychczasowego życia daleko od Boga, „bo to zaprawdę tu u nas wielki dziw, gdy się jaki człowiek z tamtego obłędnego świata i z dziwnych omyłek jego do nas nawróci a dobrowolnie przydzie” (W., s. 69).

Dla przewodników istotne jest nie tylko to, aby Krześcijanin poznał słowa Biblii - zrozumiał je i stosował każdego dnia. W końcowych partiach rozmowy uczeń dowiaduje się, że jego nawrócenie nie stanowi kresu drogi. Musi wypełnić swoje zobowiązanie wobec Boga, dlatego zostaje posłany, by nauczać ludzi, którzy - tak jak on kiedyś - nie stosują się do słów Pisma Świętego. Anioł, by pokazać uczniowi, że jest gotowy do wykonania tego zadania, mówi: „Pierwej ci się wszystko zdało coś trudnego a nieznośnego ku wytrwaniu, teraz już, jako baczę, żeć wszystko ku myśli przystawa, czegoś się pirwej zbraniał” (W., s. 89). Jest to zdanie podsumowujące postępy dokonane przez Krześcijanina w czasie ich wspólnej wędrówki, a wagę i pożyteczność powierzonej uczniowi roli obrazują słowa: „Snadź żadne złoto ani srebro nie jest tak płatne jak nauka prawdy, bo wszystko z czasem swoim przeminie [...], a Słowo Pańskie prawdziwe to trwa na wieki wieczne" (W., s. 91). Anioł, świadom słabości człowieka, opowiada przypowieść biblijną o nieposłusznym słudze, który wbrew woli swojego pana zakopał otrzymany od niego dar (Mt 20, 14-30). Przywołana historia stanowi zachętę dla Krześcijanina, by nie zachowywał dla siebie wiedzy zdobytej dzięki przewodnikom, ale dzielił się nią z innymi ludźmi. Jest to również przestroga przed niewykonaniem powierzonego mu zadania, ponieważ może zostać ukarany tak jak nieposłuszny sługa z przypowieści. Anioł uświadamia Krześcijaninowi, że dzielenie się darami Boga jest jego obowiązkiem.

Celem utworu Lubelczyka jest nakłonienie czytelników do uznania poglądów twórcy za słuszne i stosowania się przez nich do proponowanych przez autora wskazówek moralnych. Wykorzystanie perswazji w celach parenetycznych zaobserwować można już w samym tytule, który w całości brzmi: Wirydarz krześcijański pięknie przyprawiony, a z Pisma Świętego wdzięcznymi zioły zasadzony, ku pociesze wiernym ludziem za Krystusem krzyż noszącym nowo uczyniony i uszczepiony. Umiejscowieniem akcji dzieła w wirydarzu i wyraźnym zasygnalizowaniem tego w tytule autor chce wpłynąć na wyobraźnię odbiorcy. Jak już wspomniano, przyklasztorne ogrody pełniły funkcję mistyczną, służyły kontemplacji, były wolne od grzechów świata zewnętrznego. Lubelczyk, tytułując swój utwór w ten sposób, wskazuje, że czytanie jego dzieła powinno 
odbywać się w skupieniu oraz z pełnym zaangażowaniem. W tytule kryje się także zapowiedź zmiany, która ma zajść w człowieku podczas lektury. Autor chce, aby odbiorca po skończeniu czytania narodził się na nowo, czego wyrazem są słowa: „[...] ku pociesze wiernym ludziem [...] nowo uczynionym i uszczepionym" (W., s. 19). Wpisana w tytuł metafora zawartych w Piśmie Świętym treści jako wdzięcznych ziół, które mają nieść pocieszenie i być nagrodą dla człowieka wierzącego, stanowi zachętę dla czytelnika, ma go też zaciekawić oddziałującymi na zmysły słowami.

Formuły tytułowe poprzedzające kolejne „cząstki” oraz rozdziały utworu również mają określone funkcje. Informują one o treści danego fragmentu dzieła, jak np.: „O wirydarzu Pisma Świętego i o kluczach jego” (W., s. 25), „Skąd człowiek krześcijański czasu krzyża a utrapienia sobie wspomożenia i pociechy szukać ma, a gdzie ją najrychlej znaleźć może” (W., s. 59). Wśród tytułów jednak znacznie przeważają te mające formę jasnych oraz precyzyjnych tez i sądów, będących przedmiotem rozważań w danym rozdziale, np.: „İ̇ krześcijani tu na ziemi bez krzyża a ucierpienia nigdy być nie mogą” (W., s. 31), „Że krzyż a zamutek jest barzo potrzebny a pożyteczny ludziom krześcijańskim” (W., s. 48). Takie formułowanie śródtytułów kolejnych części utworu sprzyja także przejrzystości wykładu. Po zaznajomieniu się z jednoznaczną, klarownie wyselekcjonowaną oraz wyodrębnioną w postaci tytułu tezą czytelnik ze znaczną łatwością może podążać za wywodem autora dotyczącym trudnych spraw moralności i wiary.

Lubelczyk w Wirydarzu przyjmuje postawę parenetyczną wobec swojego odbiorcy. Stara się przekonać go o „wysokiej wartości sugerowanych mu wzorców osobowych i zachęcić do ich naśladowania” (Dziechcińska, 2002, s. 618). Perswazja realizuje się w ramach wymowy doradczej (genus deliberativum), mającej najszersze zastosowanie w „różnorodnych gatunkach prozatorskich i wierszowanych literatury dydaktyczno-moralizującej” (Korolko, 1990, s. 47-48). Rodzaj ten obejmuje wypowiedzi suasio („zachęcające”) oraz dissuasio („odradzające”) (Lausberg, 2002, s. 129). W Wirydarzu najważniejszym elementem zachęcania i odradzania są przykłady z Pisma Świętego. Po przedstawieniu tezy autor od razu przechodzi do potwierdzania jej słuszności słowami z Biblii, które nie tylko ją wzmacniają i utrwalają w świadomości odbiorcy, ale także dowodzą jej niepodważalnej prawdziwości. Lubelczyk często nie poprzestaje na jednym cytacie, co ma pokazać, że podejmowane przez niego kwestie są również wielokrotnie poruszane zarówno w Starym, jak i Nowym Testamencie.

W przedmowie „ku krześcijańskiemu czytelnikowi” pisarz zaznacza, że słowa kieruje do ludzi wierzących w Jezusa, którzy czasami błądzą. Największą wartością jego dzieła jest to, że może ono pomóc w powrocie na odpowiednią drogę. Autor wymienia liczne pożytki wynikające z „pilnego i rozsądnego” zapoznania się z jego utworem, takie jak: pocieszenie w smutku, wskazanie środków, jakimi należy walczyć z grzechem. Przedmowa do Jakuba Zuttera zawiera obietnicę, że sumienna lektura tekstu będzie dla odbiorcy owocna (Sitkowa, 2002, s. 46). By zjednać sobie czytelnika, Lubelczyk wykorzystuje topos skromności (Curtius, 2005, s. 80) - pisze: „A jeśliż tu co nie w traf, / A wszak to nie wczoraj - / Przydać się namędrszemu [...]” (W., s. 24). Zaznacza, że jego umysł nie jest doskonały i jak każdy człowiek może popełniać błędy. Pokora pisarza ma pokazać, że jest podobny do swoich czytelników. Przekonuje jednak, że przekazuje jedynie nauki Pisma Świętego, a głównym ich twórcą i głosicielem jest Jezus: „Jednoć w to sam Krystus Pan / Ugodził tak cale, / Iż nam nauki swoje / Podał doskonale” (W., s. 24). 
Innym czynnikiem umożliwiającym autorowi zbudowanie relacji z odbiorcą jest wykorzystanie formy dialogu do wyłożenia swoich poglądów. Sprawia to, że utwór nie ma jedynie charakteru umoralniającego wykładu, czyniącego z czytelnika biernego słuchacza, ale jest to rozmowa uwzględniająca człowieka, który odnajduje swojego reprezentanta w postaci Krześcijanina. W ten sposób Lubelczyk daje odbiorcy poczucie, że może być on równorzędnym uczestnikiem dialogu. Pozwala mu zabrać głos, choć nie bez znaczenia pozostaje fakt, że w wypowiedziach chrześcijańskiego ucznia nie ma słów sprzeciwu. Lubelczyk po to czyni go jednym z interlokutorów, żeby odbiorca znalazł w utworze postać, z którą może się utożsamić. Skutkiem tego powinien być emocjonalny stosunek czytelnika do opisywanej historii. To są główne cele obecności Krześcijanina w dialogu, nie zaś głoszenie sądów sprzecznych z ideologiczną wymową utworu. W wypowiedziach Anioła traktujących o powinnościach chrześcijan często używane są pierwsza oraz trzecia osoby liczby mnogiej, np.: „przy krzcie świętym na piersiach bywamy znaczeni znamieniem krzyża świętego, to dlatego abychmy z uprzejmego serca, ochotnie znosili krzyż swój...” (W., s. 36). Odbiorca ma możliwość poczuć wspólnotę z innymi wierzącymi ludźmi oraz istotami służącymi Bogu, którymi są aniołowie. Autor w ten sposób uzmysławia czytelnikowi, że nie jest osamotniony w swoich ziemskich zmaganiach i skoro obaj są chrześcijanami, to dzielą ten sam los. Odwołanie się Lubelczyka do wspólnych doświadczeń pomaga sprawić, że odbiorcy zaczyna zależeć na bohaterach i pozostanie on w emocjonalnym związku z przekazywanymi treściami.

W Wirydarzu nie ma stwierdzeń polemicznych. Autor nie chce wprowadzać do utworu sądów opozycyjnych, wywołujących chaos i utrudniających odbiór dzieła zgodny z jego intencją. Wywód poprowadzono w sposób jasny, precyzyjny, poparty argumentami najwyższej rangi, czyli zapożyczonymi z Biblii oraz tekstów św. Augustyna. Częstym oraz istotnym elementem wypowiedzi Lubelczyka są cytaty pochodzące w znacznej większości z Pisma Świętego. Tym samym autor sygnalizuje, że zna słowa zapisane w tej najważniejszej dla chrześcijan księdze i czerpie z nich. Odbiorcy mogą wierzyć, że to, co przekazuje im pisarz, nie jest herezją. Świadomość, że wśród czytelników mogą znaleźć się przeciwnicy wyznawanych przez Lubelczyka prawd, pozwala mu uprzedzić ich wątpliwości. Autor niejednokrotnie odrzuca ewentualne zarzuty o nieprawdziwość głoszonych słów czy niewykonalność wymienianych przez niego powinności, będących obowiązkiem wierzących. Przykład w takich momentach stanowi postawa Jezusa, który czynił to wszystko, co zaleca Lubelczyk, i swoim życiem dowiódł zasadności obranej przez siebie drogi. Tego argumentu człowiek wierzący nie może podważyć, ponieważ (jak sam autor podkreśla) ktoś, kto nie naśladuje Jezusa, nie ma prawa nazywać się chrześcijaninem. Dające się zauważyć jednoznaczność oraz pewność pisarza dotyczące głoszonych sądów znacząco wpływają na skuteczność jego perswazji.

W pierwszej części utworu podstawowym tematem refleksji bohaterów jest krzyż będący symbolem męki Jezusa oraz drogowskazem moralnym. Wędrówkę z czytelnikiem Lubelczyk inicjuje zachętą do pozostawienia ziemskich spraw i skupienia się na tym, co naprawdę powinno przyświecać egzystencji każdego chrześcijanina. Pisze: „[...] proszę i upominam cie, abyś zaniechawszy na chwilę tego doczesnego starania około tej nędznej żywotności swojej, naprzód sobie zawżdy szukał królestwa Bożego i sprawiedliwości Jego" (W., s. 27). Zachętę dopełnia zapewnieniem, że zastosowanie się do porad nauczyciela gwarantuje bezpieczeństwo w obliczu 
choroby i śmierci, ponieważ w miejscu, do którego się udają, znajdują się niezbędne dla każdego chrześcijanina lekarstwa. Wizja życia pod opieką Boga skłania Krześcijanina do dalszej wędrówki ze swoim przewodnikiem. Motyw pielgrzymowania Lubelczyk realizuje w dwojaki sposób - jako poszukiwanie sensu cierpienia, odkrywanie swojej drogi na ziemi oraz jako samodoskonalenie, duchowe wzrastanie (Meller, 2009, s. 15-16). Przewodnik zachęca Krześcijanina do wspólnego przebycia ścieżek ogrodu, by w przyszłości mógł on samodzielnie korzystać z jego dobrodziejstw: „[...] przechodź się ze mną maluczko - ukażęć tak rozkoszny ogród, a tak wdzięczny wirydarz, w którym sobie znajdziesz tak wdzięczne, a wonne ziółka, które tobie będą pożyteczne w każdej potrzebie dusznej” (W., s. 28). Doświadczając dóbr ogrodu, należy być otwartym na działanie Boga i mieć świadomość swojej niedoskonałości. Autor, poruszając kolejne kwestie dotyczące życia ludzi wierzących, kreśli obraz przyszłości. Nie pozostawia swojego odbiorcy jedynie z surowymi nakazami, licząc na jego przemianę, ale zawsze wymienia pożytki, które będą skutkiem proponowanej drogi postępowania. Pokazuje, że wiedza, którą nabywa czytający utwór, zaowocuje w dalszej perspektywie.

Dzieło Lubelczyka realizuje założenie protestanckiej nauki o przywróceniu centralnego miejsca krzyżowi, który jest symbolem zbawczej ofiary Jezusa (Meller, 2009, s. 16). Dlatego właśnie znaczną część Wirydarza stanowi wywód o obowiązku naśladowania czynów Syna Bożego. Autor wymienia kilka powodów mających zachęcić odbiorcę do postępowania zgodnie z nauką Pisma Świętego. W pierwszej kolejności powołuje się na fakt, że ktoś, kto nie podejmuje trudu dźwigania własnego krzyża, nie może nazywać się chrześcijaninem, ponieważ „Jeżeli Krystus, będąc naszą głową, cierpieć raczył, słusznie też i wierni członkowie jego cierpieć mają” (W., s. 34). Następnie Lubelczyk przechodzi do wyjaśnienia znaczenia słowa określającego wyznawców Chrystusa: „[...] niechaj sobie żaden szczęścia świata tego przed oczy swe nie przekłada, gdyż nie w tym należy własne przezwisko krześcijańskie” (W., s. 36). Godna kontynuacja dzieła zapoczątkowanego przez Jezusa zostanie wynagrodzona. Autor daje odbiorcy nadzieję (spes) (Lausberg, 2002, s. 129) zbawienia, jeśli ten nie odstąpi od rad przewodnika. Należy cieszyć się, że Bóg doświadcza swoich wyznawców, ponieważ jest to dar od Stwórcy, by człowiek mógł zapracować na życie wieczne: „[...] kto się temi żądełki ziela tego, to jest Doświadczenia, nie sparzy [...] nie może sobie tego słusznie przywłaszczyć a przyczynić, aby żył w łasce Bożej [...]” (W., s. 52). Ludzie, którzy nie zostają obarczeni krzyżem, zapominają o Bogu i nie zaznają Jego miłości.

Autor stanowczo odradza narzekanie na krzyż. Powinność, jaką jest naśladowanie Jezusa w jego dźwiganiu, stanowi jeden z najważniejszych tematów podjętych przez Lubelczyka i dlatego - by udowodnić swoją tezę - zastosował on nagromadzenie cytatów z Nowego Testamentu. W pierwszej kolejności autor przywołuje słowa samego Jezusa: „[...] kto chce mnie wiernie naśladować a za mną ić, niechże weźmie a niesie krzyż swój” (Mt 15, 24)², następnie: „[...] przez wiele trudności musimy wchodzić do królestwa Bożego” (Dz 14, 22), oraz: „[...] wszyscy ci, którzy w Krystusie Jezusie pobożnie a cnotliwie żyć chcą, takowi wielkie a rozliczne

2 Zawarte w Wirydarzu fragmenty pochodzące z Pisma Świętego mogą być tłumaczeniami sporządzonymi przez samego autora lub zaczerpniętymi z przekładu Nowego Testamentu Stanisława Murzynowskiego oraz Psałterza M. Reja, zob. Meller, 1990, s. 14. 
przenaśladowanie cierpieć muszą” (2 Tm 3, 12). Przywołuje również słowa św. Piotra: „[...] tak jako i Krystys Pan cierpieć raczył dla nas, wszystko to uczynił, zostawując nam przykład, abychmy naśladowali stóp i ścieżek jego" (1 P 2, 21). Wielość cytatów ma pokazać, że nie bez powodu autor poświęca tematowi krzyża znaczną część wywodu. W samym Nowym Testamencie stanowi on bowiem kwestię kluczową i wielokrotnie poruszaną. Dydaktyczny cel, a więc główne założenie utworu Lubelczyka, wymaga wyrazistego przedstawienia myśli - by to uczynić, autor posługuje się kontrastowymi zestawieniami. Odradzając czytelnikowi rezygnację z powinności dźwigania krzyża, autor nie skupia się jedynie na opisie tego, co spotka postępujących zgodnie $\mathrm{z}$ nauką Jezusa, ale, by przestrzec odbiorcę przed konsekwencjami odstąpienia od jego ostrzeżenia, pokazuje ludzi postępujących źle i zapewnia, że oni również otrzymają to, na co zapracowali swoim niegodnym zachowaniem. Wizja przyszłości tych, którzy nie naśladują swojego Pana, ma wzbudzić w czytelniku obawę (metus) (Lausberg, 2002, s. 129) i skutecznie odwieść go od niewypełnienia swojej powinności jako chrześcijanina. Autor przestrzega także przed zgubną zazdrością wobec tych, którzy wydają się szczęśliwi bez Boga, ponieważ „nic się gorszyć nie masz, przekładając sobie przed oczy swe szczęście ich, ale się masz pilnie oglądać na koniec a na zapłatę tych obu stron, to jest złych i wiernych [...]" (W., s. 34).

W wypowiedziach zniechęcających (dissuasio) Lubelczyk wykorzystuje wyraźne rozgraniczenie pomiędzy tym, co złe, i tym, co dobre, aby nie pozostawić czytelnikowi wątpliwości oraz nie stwarzać możliwości mylnych interpretacji. Autor przedstawia wizję świata, w którym życie polega na ciągłej walce ze złem, z Szatanem i ciałem. Koncepcja ta wywodzi się z protestanckiej wizji przybitego do krzyża Chrystusa, którego należy naśladować (Meller, 2009, s. 17). Wyparcie się krzyża i Jezusa, odradzane przez Lubelczyka, decyduje o rychłej przegranej. W Wirydarzu pokazane są obrazy zagłady ludzi, do której doprowadziły „rozliczne chytrości” czarta (W., s. 37). Mają one odwieść człowieka od złego postępowania dzięki wzbudzeniu w nim strachu przed zgubnymi konsekwencjami. Aby skuteczniej zadziałać na wyobraźnię odbiorcy, autor stosuje topos podobieństwa (Korolko, 1990, s. 66). Ponieważ Szatan jest dla ludzi postacią abstrakcyjną, Lubelczyk wykorzystuje obrazy znane, namacalne (jak: rąbanie drzewa czy sztorm na morzu), aby uświadomić czytelnikowi skalę szkód, które Zły może uczynić w życiu chrześcijan. Autor chce wpłynąć na odbiorcę, wzbudzając w nim strach oraz antypatię do istot chcących zerwać jego więź z Bogiem.

Lubelczyk posługuje się przykładami starotestamentowych proroków, takich jak: Abraham, Izaak, Jakub, Józef, Dawid i Ezajasz (Izajasz), którzy mimo prób, na jakie wystawiał ich Stwórca, pozostawali nieugięci w wierze. Przywołuje także postać Jezusa poddanego „srogim troskam, smutkom i kłopotom, a na ostatek okrutnej a gorzkiej śmierci krzyżowej” (W., s. 51). Autor przypomina, że również Maryja i wielu świętych było doświadczanych rozlicznymi niedogodnościami, które nie zdołały oddalić ich od Stwórcy. Nagromadzone przez pisarza przykłady dowodzą, że nie żąda on od czytelnika rzeczy niemożliwych do wykonania. Osoby obecne w Biblii stanowią niepodważalny oraz konieczny do naśladowania wzór dla chrześcijan. Lubelczyk wykorzystuje kulturowo utrwalone podobieństwo (Korolko, 1990, s. 66) między ojcem i Bogiem, by wyjaśnić konieczność doświadczania oraz karania ludzi. Stwórca pragnie, by jego wyznawcy doskonalili się duchowo, ponieważ tak jak ojciec chce rozwoju swoich dzieci, „On tak jako prawy ociec równie obchodzić chce z nami jako z dziatkami swemi, gdy je chce mieć posłusznemi 
sobie, musi iście brzozy nie szanować [...]” (W., s. 47). Karanie nie jest spowodowane okrucieństwem, ale chęcią stworzenia szansy udowodnienia wiary przez chrześcijanina.

W postaci Krześcijanina Lubelczyk prezentuje swoje przekonanie o tym, jaki powinien być wzorowy wyznawca Chrystusa. Bohater przyjmuje nauki przewodników, ale nie jest zupełnie bierny, komentuje rzeczywistość, która go otacza, zadaje pytania, mówi o swoich dotychczasowych poglądach i konfrontuje je z poznawanymi prawdami. Autor w ten sposób chce uzmysłowić człowiekowi, że próba zdobycia wiedzy oraz jej zaadaptowanie do życia nie następują nagle, tylko stopniowo. Krześcijanin swoje zaangażowanie pokazuje poprzez podsumowywanie i streszczanie nauk przewodników, a nawet odnoszenie ich do własnych doświadczeń. Ukazuje, jak dzięki słowom nauczycieli zmienia się jego postrzeganie świata oraz wiary, np.: „Wszystkom ci ja sobie tak mnimał, żeby to było ono drzewo, co na niem Krystus Pan cirpiał, aleciem się już teraz temu jawnie a jaśnie przysłuchał i doskonalem sobie wziął w rozum, iż to nie o drzewo ma być rozumiano!" (W., s. 39). Protagonista zadaje również wiele pytań, co ma pokazać, że nie jest jedynie słuchaczem, ale zaczyna rozmyślać nad poruszanymi kwestiami, oraz że teraz nie świat materialny, ale duchowy jest tematem jego refleksji. Czasami są to pytania, które wymagają jedynie doprecyzowania przez nauczycieli omawianych zagadnień, ale są też takie, które wprowadzają nowy wątek, np. bohater pyta o to, czy stawianie krzyży przy drogach i w domach to przejaw wiary, czy może zakłamania i pozornej religijności.

W wypowiedziach Krześcijanina można dostrzec radość, którą czerpie ze zdobywanej wiedzy; sam zachęca przewodników, żeby opowiadali mu więcej i prowadzili dalej: „[...] i widzieć i słyszeć miło, pośle święty, takowych zacnych a poważnych rzeczy, które i oczy, i uszy moje tak wdzięcznie delektują [...]” (W., s. 53). Bohater opisuje również zmiany, jakie w nim zachodzą, mówi, że słowa przewodników pobudzają jego wcześniej uśpioną duszę: „[...] duszyczka moja jakoś we mnie trzeźwieje a dziwnie się rozkochywa” (W., s. 55). Autor w ten sposób pokazuje, że treści głoszone przez nauczycieli mają wpływ na Krześcijanina i powinny też oddziaływać na czytelników, którzy utożsamiają się z protagonistą. Często zaznacza, że nie należy wątpić w słowa przewodników - bohater obiecuje stosować się do ich poleceń. Pokornie odpowiada na zarzuty o słabej wierze i przyznaje się do swojej ułomności. Świadomość grzeszności budzi w Krześcijaninie lęk i stanowi motywację do pracy nad sobą.

W Wirydarzu Lubelczyk podejmuje także temat wewnętrznych konfliktów w Kościele. Obrazuje je przypowieścią o Jakubie i Ezawie, synach Rebeki i Izaaka, walczących z sobą już w łonie matki. W utworze niepokoje dręczące Kościół odzwierciedla za pośrednictwem metafory łódki, którą Szatan chce zatopić (Kobielus, 2000, s. 159-161). Wyznawcy Chrystusa nieustannie narażeni są na próby, którym trudno sprostać, szczególnie w czasach wyznaniowego zamętu. Człowiek może poczuć się zdezorientowany, a w konsekwencji zaprzestać wszelkich starań nad umacnianiem wiary, dlatego pisarz daje ludziom dzieło będące pocieszeniem i objaśnieniem zawiłości Pisma Świętego.

Na związek Lubelczyka z reformacją wskazuje nie tylko treść omawianego utworu, ale również jego bliska współpraca z innym protestanckim twórcą - Mikołajem Rejem. Autor Wirydarza na rzecz ruchu reformacyjnego tworzył modlitwy, pieśni, podręczniki i przekładał psalmy (Meller, 2009, s. 6). Lubelczyk odwzorował w dziełach Rejowe formy pisarskie, wykorzystanie perswazji, koncepcję pisarza jako nauczyciela i przewodnika oraz język. W Wirydarzu można 
odnaleźć inspiracje przede wszystkim dwoma utworami Nagłowiczanina - Postylla oraz Wizerunkiem. Cechą wspólną wymienionych tekstów Reja oraz dialogu Lubelczyka jest podjęcie przez autorów roli nauczyciela, by zrealizować dydaktyczno-moralizatorskie przesłanie kierowane do szerokiego grona odbiorców (Maciuszko, 2002, s. 421). W Postylli nauka jest przekazywana bezpośrednio. Natomiast w Wizerunku to młodzieniec podróżujący po świecie w poszukiwaniu cnoty i wiedzy dzięki przebytej drodze staje się wzorem godnym naśladowania (Brückner, 1905, s. 152) (w Wirydarzu taką rolę odgrywa Krześcijanin). Dzieło Lubelczyka obfituje w cytaty pochodzące z Pisma Świętego, które mają przybliżyć odbiorcy słowa zawarte w tej księdze. Rej w Postylli również umieścił fragmenty oraz przykłady z Biblii - był to zabieg charakterystyczny dla przedstawicieli protestantyzmu. Zarówno dla warsztatu Reja, jak i Lubelczyka bardzo ważna była reformacyjna zasada sola Scriptura, zachęcająca, by samodzielnie docierać do prawdy poprzez obcowanie z Pismem Świętym. W Postylli oraz Wirydarzu oprócz zwrotu do czytelnika w drugiej osobie liczby pojedynczej często pojawia się forma „my” - wyrażająca poczucie wspólnoty, bliskości oraz analogię do sytuacji, w której znajduje się nadawca i odbiorca (Maciuszko, 2002, s. 413). Aleksander Brückner zwraca uwagę na to, że w Postylli są „streszczenia, punkty albo sumuły całego kazania” przypominające nazwy rozdziałów obecnych w dziele Lubelczyka (Brückner, 1905, s. 99). Utrwalają one przede wszystkim wiedzę przekazaną w danym fragmencie. Wykazane zależności pomiędzy Wirydarzem a utworami Reja pokazują, że zabiegi wykorzystane przez sekretarza Nagłowiczanina w dydaktycznych celach nie były charakterystyczne jedynie dla jego twórczości, ale praktykowane przez przedstawicieli ruchu reformacyjnego, a szczególnie - Reja.

Wirydarz krześcijański to utwór o silnie wyeksponowanej funkcji dydaktycznej. Nie stanowi jedynie wiernego odwzorowania Biblii, ale jest dziełem dającym wyznawcom Jezusa przykład odpowiedniego postępowania. Rozważania nad kolejnymi etapami przemiany Krześcijanina pokazały, że perswazja realizowana za pomocą mowy doradczej (genus deliberativum) ostatecznie przynosi rezultat i bohater, który niegdyś należał wyłącznie do świata ziemskiego, zostaje włączony do wspólnoty ludzi wierzących.

\section{Bibliografia podmiotowa}

Lubelczyk, J. (2009). Wirydarz krześcijański pięknie przyprawiony... Apoteka Ducha świętego. Wstęp i oprac. K. Meller. Lublin: Wydawnictwo Uniwersytetu Marii Curie-Skłodowskiej.

\section{Bibliografia przedmiotowa}

Abramowska, J. (2002a). Dialog [hasło]. W: T. Michałowska i in. (red.), Słownik literatury staropolskiej (s. 159-163). Wrocław: Zakład Narodowy im. Ossolińskich - Wydawnictwo Polskiej Akademii Nauk. Abramowska, J. (2002b). Moralitet [hasło]. W: T. Michałowska i in. (red.), Słownik literatury staropolskiej (s. 485-488). Wrocław: Zakład Narodowy im. Ossolińskich - Wydawnictwo Polskiej Akademii Nauk. 
Brückner, A. (1905). Mikołaj Rej: studium krytyczne. Kraków: Skład Główny w Księgarni Spółki Wydawniczej Polskiej.

Ciołek, G. (1978). Ogrody polskie. Wyd. 2. Warszawa: Arkady.

Curtius, E.R. (2005). Literatura europejska i łacińskie średniowiecze. Przekł. i oprac. A. Borowski. Kraków: TAiWPN Universitas.

Dąbkowska, J. (1997). Wprowadzenie do lektury. W: S. Grochowski. Wirydarz abo kwiatki rymów duchownych o dziecięciu Panu Jezusie (s. 5-17). Warszawa: Instytut Badań Literackich.

Dąbrówka, A. (2001). Teatr i sacrum w średniowieczu. Wrocław: Wydawnictwo Naukowe Uniwersytetu Mikołaja Kopernika.

Dziechcińska, H. (2002). Parenetyka [hasło]. W: T. Michałowska i in. (red.), Słownik literatury staropolskiej (s. 618-623). Wrocław: Zakład Narodowy im. Ossolińskich - Wydawnictwo Polskiej Akademii Nauk.

Erzepki, B. (1883). Literatura polska. Jakuba Lubelczyka „Wirydarz krześcijański”. Nieznany druk polski z r. 1558. Dziennik Poznański, 25 (28), 1-2.

Eustachiewicz, M. (1975). Poeta w ogrodzie: ogród jako motyw ramy renesansowych i barokowych zbiorów poetyckich. Pamiętnik Literacki, 66 (3), 3-38.

Kobielus, S. (2000). Krzyż Chrystusa. Od znaku i figury do symbolu i metafory. Warszawa: PAX.

Komorowska, M. (2012). Seria „Lubelska Biblioteka Staropolska”. Terminus, 14 (1), 265-268.

Korolko, M. (1990). Sztuka retoryki. Przewodnik encyklopedyczny. Warszawa: Wydawnictwo Wiedza Powszechna.

Kossowska, K. (2018). Lubelska Biblioteka Staropolska - o serii wydawniczej. Sztuka Edycji, 2, 140-147.

Kramarek, G. (2006). Lubelczyk Jakub. W: E. Ziemann (red.), Encyklopedia katolicka (kol. 22-23). T. 11. Lublin: Towarzystwo Naukowe KUL.

Krenz, M. (2005). Średniowieczna symbolika wirydarzy klasztornych. Kraków: Wydawnictwo Nomos.

Künstler-Langer, D. (2007). Anioł w poezji baroku. Dzieje postaci w kulturze dawnej Europy. Toruń: Wydawnictwo Naukowe Uniwersytetu Mikołaja Kopernika.

Kuran, M. (2014). Wirydarz [hasło]. W: F. Gryglewicz (red.), Encyklopedia katolicka (kol. 685-687). T. 20. Lublin: Towarzystwo Naukowe KUL.

Lausberg, H. (2002). Retoryka literacka. Podstawy wiedzy o literaturze. Przekł. i oprac. A. Gorzkowski. Bydgoszcz: Wydawnictwo Homini.

Maciuszko, J.T. (2002). Mikołaj Rej - zapomniany teolog ewangelicki z XVI w. Warszawa: Chrześcijańska Akademia Teologiczna.

Maleszyńska, J. (1984). Staropolskie ogrody literackie: między topiką a genologią. Pamiętnik Literacki, 75 (1), 3-32.

Meller, K. (1980). Zapomniane dzieło Jakuba Lubelczyka. Ruch Literacki, 21 (2), 135-140.

Meller, K. (1990). Jakuba Lubelczyka „Wirydarz krześcijański”. W: T. Ulewicz (red.), Miscellanea staropolskie (s. 5-15). T. 6. Wrocław: Zakład Narodowy im. Ossolińskich - Wydawnictwo Polskiej Akademii Nauk.

Meller, K. (2009). Wprowadzenie. W: J. Lubelczyk. Wirydarz krześcijański pięknie przyprawiony... Apoteka Ducha świętego (s. 5-18). Wstęp i oprac. K. Meller. Lublin: Wydawnictwo Uniwersytetu Marii Curie-Skłodowskiej.

Pelc, J. (1971). Dialog i wizerunek. Dwa dominujące typy konstrukcji wypowiedzi w poetyce Reja. W: T. Bieńkowski, J. Pelc, K. Pisarkowa (red.), Mikołaj Rej w czterechsetlecie śmierci (s. 129-157). Wrocław: Zakład Narodowy im. Ossolińskich - Wydawnictwo Polskiej Akademii Nauk.

Pollak, R. (1964). Lubelczyk Jakub [hasło]. W: T. Pollak (red.), Bibliografia literatury polskiej. „Nowy Korbut” (s. 457-459). T. 2. Warszawa: Państwowy Instytut Wydawniczy. 
Sayers, D.L. (1975). O pisaniu i czytaniu utworów alegorycznych. Tłum. P. Graff. Pamiętnik Literacki, 66 (3), s. 195-216.

Sitkowa, A. (2002). O przedmowach Piotra Skargi. W: R. Ocieczek (red.), Przedmowa w książe dawnej i współczesnej (s. 37-52). Katowice: Wydawnictwo Gnome.

Skwarczyńska, S. (1969). Kariera literacka form rodzajowych „silva”. W: J.Z. Jakubowski, J. Kulczycka-Saloni, Z. Libera (red.), Europejskie związki literatury polskiej (s. 37-75). Warszawa: Państwowe Wydawnictwo Naukowe.

Tuve, R. (1975). Alegoria narzucona. Tłum. R. Zimand. Pamiętnik Literacki, 66 (4), s. 177-190.

\section{Didacticism work in the "Christian garden" by Jakub Lubelczyk}

\section{Summary}

The article is based on the analysis of the way that didacticism works in the "Christian garden" ("Wirydarz krześcijański") by Jakub Lubelczyk (1530-1563). The paper focuses primarily on the characteristics of the main character (Krześcijanin) and his spiritual transformation, which is the result of a conversation with the guides. The next stages of the Krześcijanin development have shown the persuasion, which was used by the author through deliberative rhetoric (genus deliberativum), encouraging (suasio), and discouraging (dissuasio) statements. Lubelczyk articulates his arguments based on the Holy Bible, moral guidelines and ideas created from a perspective of the Reformation movement. "Christian garden" was juxtaposed with the selected literary works of Mikołaj Rej, which show that the rhetorical measures used by Lubelczyk for didactic purposes were also used by other artists.

Słowa kluczowe: wirydarz, Jakub Lubelczyk, dydaktyka, perswazja, piśmiennictwo religijne

Keywords: garden, Jakub Lubelczyk, didactics, persuasion, religious literature 
http://rcin.org.pl 